\title{
PENGARUH CUSTOMER INTIMACY, PROMOSI, DAN CITRA MEREK ISLAM TERHADAP LOYALITAS NASABAH BANK SYARIAH INDONESIA KCP GODEAN 3 DENGAN KEPUASAN SEBAGAI VARIABEL INTERVENING
}

\author{
Naslikhatun Nafiah ${ }^{1}$, Abdul Aziz Nugraha Pratama ${ }^{2}$ \\ Fakultas Ekonomi dan Bisnis Islam IAIN Salatiga, Indonesia ${ }^{1,2}$ \\ Email : naslikhatunnafiah04@gmail.com, pratama_abdul@yahoo.com
}

\begin{abstract}
This study aims to examine the effect of customer intimacy, promotion, and Islamic brand image on customer loyalty at Bank Syariah Indonesia KCP Godean 3 with satisfaction as an intervening variable. The research method is quantitative in the form of primary data obtained through distributing questionnaires to customers of Bank Syariah Indonesia KCP Godean 3. The samples taken are 100 respondents. The sampling technique used is purposive sampling. Then the results obtained are processed with SPSS version 22. The results show that customer intimacy has a significant positive effect on loyalty with a coefficient of $23.8 \%$ and a significance of $<5 \%$. Promotion has a positive and insignificant effect on loyalty with a coefficient of $1.9 \%$ and a significance $>5 \%$. Islamic brand image has a positive and significant effect on loyalty with a coefficient of $35.3 \%$ and a significance of $<5 \%$. Satisfaction has a positive and significant effect on loyalty with a coefficient of $47.7 \%$ and a significance $<5 \%$. Customer intimacy has a significant positive effect on satisfaction with a coefficient of $64.0 \%$ and a significance of $<5 \%$. $\%$. Promotion has a positive and insignificant effect on satisfaction with a coefficient of $1.4 \%$ and a significance $>5 \%$. Islamic brand image has a positive and significant effect on satisfaction with a coefficient of $91.0 \%$ and a significance of $<5 \%$. Satisfaction is not able to mediate customer intimacy on loyalty with a $t$ count of $39.495 \%<t$ table 1.661 with a significance level of $5 \%$. Satisfaction is not able to mediate promotion of loyalty with a t count of $39.103 \%<t$ table 1.661 with a significance level of 5\%. Satisfaction is able to mediate Islamic brand image on loyalty with t count of $419.041 \%>$ t table 1.661 with a significance level of $5 \%$.
\end{abstract}

Keywords: customer intimacy, promosi, citra merek Islam, kepuasan, loyalitas.

Salah satu fenomena baru dalam dunia ekonomi modern yang bisnisnya belakangan ini menunjukkan prospek peningkatan yang luar biasa adalah perbankan syariah. Terbukti dengan adanya pesaing yang ketat berupa banyaknya produk dan jasa yang disediakan bank syariah membuat pelaku bisnis harus pandai berinovasi sekreatif dan seoptimal mungkin menjaga mutu pelayanan yang berkualitas secara maksimal agar tetap eksis di bidang usaha yang ditekuni serta menarik minat konsumen untuk menggunakan produknya (Anggriawan et al., 2015)

Berdirinya bank syariah di Indonesia diprakarsai oleh Majelis Ulama Indonesia (MUI) dan dipioniri oleh Bank Muamalat Indonesia. Setelah itu banyak sekali dari bank konvensional yang membuka juga layanan jasa syariah misalnya 
saja Bank Syaria Indonesia (BSI). Bank Syariah Indonesia merupakan bank yang memanfaatkan kerangka syariah yang sesuai dengan ajaran Islam pada sistem pembiayaannya yang merupakan hasil marger dari anak perusahaan BUMN yaitu PT Bank BRI Syariah Tbk, PT Bank Syariah Mandiri, dan PT Bank BNI Syariah dan telah efektif beroperasi per 1 Februari 2021 dan telah efektif beroperasi per 1 Februari 2021 (www.bankbsi.co.id, 2021)

Pada tahun 2021, Bank Syariah Indonesia mendapat kehormatan sebagai Statisfaction, Loyalty, dan Enggagement (SLE) Awards ke dua setelah Bank Muamalat, hal tersebut didasarkan pada hasil riset untuk menilai tingkat kepuasan, loyalitas dan keterkaitan. Jadi, dari uraian mengenai fenomena loyalitas tersebut meskipun menjadi terbaik ke dua loyalitas nasabahnya setelah Bank Muamalat Indonesia bukan berarti Bank Syariah Indonesia harus berpuas diri. Inovasi, layanan, dan juga produk tentu harus terus ditingkatkan guna mewujudkan nasabah yang loyal. Pasalnya bank syariah lain juga sebagai kompetitor tentu saja akan terus mengikuti langkah-langkah Bank Muamalat Indonesia untuk bisa mengalahkan dari sisi apapun (Hafil, 2021).

Adanya kompetensi dan suatu inovasi yang selalu dikembangkan dan diperbaiki membuat setiap perbankan harus meningkatkan suatu alasan yang menjadikan faktor apa yang mampu membuat nasabah semakin loyal. Loyalitas merupakan suatu kombinasi ikatan dan kebutuhan yang dilakukan antara nasabah dan perusahaan yang sifat dan bentuknya tidak dapat dipaksakan walaupun bisa dikelola dan diukur. Nasabah yang loyal merupakan tindakan yang berhubungan dengan identitas sebuah produk tertentu serta memungkinkan penggunaan diwaktu mendatang. Apabila suatu produk ternyata tidak bisa membuat nasabah merasa puas, maka secara langsung nasabah akan memutuskan untuk tidak melanjutkan pembelian produk dari suatu perusahaan (Warindrasti \& Pratama, 2021).

Customer intimacy merupakan suatu cara pelayanan yang berkualitas yang dilakukan dengan jalinan ikatan yang kuat. Perusahaan biasanya akan mengetahui seluk beluk dari nasabahnya sehingga mereka nyaman karena kebutuhannya selalu 
terpenuhi. Kedekatan yang terjalin dapat menimbulkan komunikasi yang efektif antara perusahaan dengan pelanggan, untuk itu kesalah pahaman sangat minim terjadi serta rasa pengertian dapat menimbulkan kontibusi positif kedua belah pihak dapat terjalin (Sidabutar \& Dharmayanti, 2015).

Promosi merupakan upaya penawaran produk dan pemberitahuan informasi yang dilakukan agar konsumen dapat tertarik agar membeli atau menggunakan produk tersebut. Kegiatan promosi dilaksanakan sebaik mungkin dalam bisnis perbankan dilakukan agar bisa menunjang penjualan produk dengan tujuan agar nasabah itu menjadi tertarik dan bersedia menggunakan produk yang ditawarkan, sehingga tujuan dari bank itu sendiri dapat tercapai (Sarwita, 2017).

Merek atau brand adalah tanda, nama, istilah yang digunakan untuk membedakan barang dan jasa dari penjual. Pada sektor bisnis syariah, kepatuhan syariah harus secara total. Ini menyiratkan bahwa merek harus memuaskan semua bagian merek untuk konsumen muslim, karena konsumen muslim hanya menggunakan barang atau jasa yang memenuhi hukum dan norma Islam. Islamic branding merupakan suatu konsep baru yang sesuai dengan syariah islam yang banyak memunculkan nilai kejujuran. Tujuan dari branding Islam yang menerapkan empati dengan nilai syariah untuk menarik konsumen muslim dengan kehalalan produknya sesuai dengan syariat Islam (Ranto, 2013).

Customer satisfaction (kepuasan pelanggan) adalah sifat atau perasaan individu yang merasa senang atau bingung ketika melihat bentuk hasil suatu barang dan merupakan salah satu variabel yang mempengaruhi pembelian ulang nasabah (Razak \& Oliver, 2018).

Penelitian tentang loyalitas nasabah sudah dilakukan oleh beberapa peneliti terdahulu. Penelitian pertama mengenai variabel customer intimacy dilakukan oleh (Anggriawan et al., 2015) yang berjudul "Pengaruh Customer Intimacy Terhadap Loyalitas Nasabah BRIS Cabang Jember". Nasabah BRI Syariah iB yang aktif dan hanya memiliki tabungan di BRI Syariah Cabang Jember yaitu sebanyak 97 responden sebgai populasinya. Pengambilan sampel menggunakan simple random sampling dan model analisis yang digunakan adalah 
analisis inferensial. Berdasarkan penelitian diatas hasilnya dapat disimpulkan bahwa customer intimacy memiliki pengaruh positif signifikan terhadap loyalitas nasabah BRI Syariah Cabang Jember.

Selanjutnya penelitian mengenai variabel promosi yang dilakukan oleh (Koyong et al., 2016) yang berjudul "Pengaruh Promosi Terhadap Loyalitas Nasabah di PT. Bank Mandiri Kantor Cabang Dotulolong Lasut Manado”. Tujuan dari penelitian ini yaitu untuk mengetahui ada tidaknya hubungan antar pelanggan. Jenisnya yaitu kuantitatif dengan pendekatan asosiatif. Sedangkan teknik analisis data menggunakan analisis regresi linier berganda dengan menggunakan aplikasi SPSS versi 25. Populasi dalam penelitian ini sebanyak 100 responden. Hasil dari penelitian menunjukkan bahwa terdapat hubungan signifikan antara promosi dengan loyalitas pelanggan.

Penelitian selanjutnya mengenai pengaruh variabel citra merek Islam oleh (Hisanuddin, 2015) yang berjudul" Pengaruh Citra Merek Islam terhadap Loyalitas Nasabah Bank Syariah studi kasus pada Bank Syariah di Kota Bandung". Tujuan utama dalam penelitian ini yaitu untuk mengetahui citra merek Islam dengan variabel citra perusahaan Islam terhadap loyalitas nasabah. Model analisis yaitu analisis jalur (path analysis).

Dari uraian diatas ternyata ada persoalan yang sangat menarik untuk dikaji yaitu adanya perbedaan hasil penelitian yang telah dilakukan oleh peneliti terdahulu mengenai customer intimacy, promosi, dan citra merek Islam terhadap loyalitas dimana masing - masing variabel memiliki hasil yang berbeda antara peneliti satu dengan lainnya sehingga peneliti tertarik untuk memperdalam serta membuktikan hasilnya. Selain itu peneliti tertarik mengambil objek Bank Syariah Indonesia dikarenakan Bank Syariah Indonesia merupakan perusahaan besar tetapi mengapa loyalitasnya masih saja kalah dengan Bank Muamalat Indonesia.

\section{METODE}

Penelitian ini menggunakan jenis penelitian lapangan (field research) serta menggunakan data primer. Pendekatannnya kuantitatif, yaitu pendekatan yang dinyatakan dalam bentuk angka, perhitungan dan juga berdasarkan dari kuisioner 
yang diberikan kepada responden. Populasi dalam penelitian ini berjumlah 6500 nasabah Bank Syariah Indonesia KCP Godean 3. Teknik sampling yang digunakan adalah non probability sampling dengan teknik pengambilan sampel menggunakan purposive sampling, karena pengambilan sampel anggota populasi dilakukan dengan cara mempertimbangkan kriteria-kriteria tertentu. Besar sampel penelitian berdasarkan rumus slovin adalah 100 responden, untuk mempermudah penelitian.

Teknik yang dipergunakan melalui penyebaran kuesioner secara tertutup dimana susunan pertanyaan yang telah ditujukan untuk objek akan dijawab pertanyaannya sehingga responden hanya memilih jawaban yang sekiranya sejalan dengan pilihannya serta dengan melalui google form yang telah dibagikan melalui aplikasi whatsapp. Setelah itu data dikumpulkan, diolah, dan dianalisis. Skala yang digunakan dalam penelitian ini adalah skala interval.

Untuk pengujian variabel intervening digunakan metode analisis jalur (Path Analysis) yang digunaan untuk memperkirakan hubungan sebab akibat antara variabel yang telah ditetapkan berdasarkan teori (Ghozali, 2013). Adapun persamaan model sebagai berikut:

$$
\begin{array}{ll}
\text { Persamaan } 1 & : Y=\alpha+\beta 1 X 1+\beta 2 \mathrm{X} 2+\beta 3 \mathrm{X} 3+\beta 4 \mathrm{Z}+\mathrm{e} \\
\text { Persamaan 2 } & : \mathrm{Z}=\alpha+\beta 1 \mathrm{X} 1+\beta 2 \mathrm{X} 2+\beta 3 \mathrm{X} 3+\mathrm{e}
\end{array}
$$

Keterangan: $\mathrm{Y}$ merupakan loyalitas, $\mathrm{Z}$ merupakan kepuasan, $\mathrm{X} 1$ merupakan customer intimacy, X2 merupakan promosi, X3 merupakan citra merek Islam. Berikutnya untuk menguji kekuatan pengaruh tidak langsung menggunakan uji sobel. Uji sobel digunakan Untuk melihat signifikan atau tidaknya pengaruh mediasi (tidak langsung) antara X ke Y melewati Z (Ghozali, 2013). Dibawah ini adalah rumus uji sobel:

$$
\mathrm{Sp} 2 \mathrm{p} 3=\sqrt{p 3^{2} S p 2^{2}+p 2^{2} S p 3^{2}+S p 2^{2} S p 3^{2}}
$$

Dimana:

p2 $=$ Coefisien variabel mediasi

p3 $=$ Coefisien variabel bebas

Sp2 = Standart error variabel mediasi 
Sp3 $=$ Standart error variabel bebas

Sebelum melakukan pengujian tersebut terlebih dahulu dilakukan uji asumsi klasik meliputi uji multikolieritas, heterokedastisitas, dan normalitas. Kemudian uji ststistik meliputi uji koefisien determinasi $\left(\mathrm{R}^{2}\right)$, uji F, dan uji T.

\section{HASIL}

Tabel 1. Hasil Regresi Persamaan 1

a. Dependent Variable: Loyalitas

Sumber: Data Primer yang diolah, 2021

Tabel 2. Hasil Regresi Persamaan 2

\begin{tabular}{|l|c|c|c|c|}
\hline \multicolumn{1}{|c|}{ Model } & Koefisien & Std.Error & T & Sig \\
\hline (Constant) & .113 & 1.993 & .056 & .955 \\
X1 & .047 & .099 & .469 & .640 \\
X2 & .014 & .050 & .272 & .787 \\
X3 & .910 & .096 & 9.437 & .000 \\
\hline
\end{tabular}

a. Dependent Variable: Kepuasan

Sumber: Data Primer yang diolah, 2021

\begin{tabular}{|lcccc|}
\hline \multicolumn{1}{c}{ Model } & Koefisien & Std. Error & T & Sig \\
\hline (Constant) & -3.003 & 1.791 & -1.677 & .097 \\
X1 & .238 & .089 & 2.661 & .009 \\
X2 & .019 & .045 & .421 & .674 \\
X3 & .353 & .120 & 2.938 & .004 \\
Z & .477 & .092 & 5.205 & .000 \\
\hline R & $.846^{\mathrm{a}}$ & & & \\
R Square & .715 & & & \\
Adjust R Square & .703 & & & \\
F & 59.664 & & & \\
Sig. F & $.000^{\mathrm{b}}$ & & & \\
\hline
\end{tabular}

\section{Uji Determinan $\mathbf{R}^{2}$}

Berdasarkan Tabel 1, nilai dari koefisien $\mathrm{R}$ yaitu: 0,846. Sehingga dapat dikatakan adanya ikatan kuat antara variabel independent customer intimacy, promosi, citra merek Islam, dan kepuasan. Selanjutnya koefisien determinasi (Adjusted $R^{2}$ ) sebesar 0,703 yang berarti variabel independen mempengaruhi variabel dependen sebesar 70,3\% sedangkan sisanya sebesar $29,7 \%$ dipengaruhi oleh variabel lain diluar model.

\section{Uji F Test}

Menurut (Ghozali, 2013), uji statistik F pada dasarnya menunjukkan apakah dari semua variabel independen yang dimasukkan dalam model mempunyai pengaruh 
secara bersamaan terhadap variabel dependen atau terikat dengan menggunakan signifikasi $<0,05$. Dalam penelitian ini memiliki F hitung sebesar 59,664 dengan nilai signifikansi 0,000 dimana nilai tersebut $<0,05$. Hasil tersebut memiliki arti bahwa setiap variabel customer intimacy, promosi, citra merek Islam, dan kepuasan berpengaruh secara positif dan signifikan terhadap loyalitas nasabah.

\section{Uji T Test}

Menurut (Ghozali, 2011), uji statistik t pada dasarnya menunjukkan seberapa jumlah pengaruh variabel independen secara individual dalam menerangkan variabel dependen. Adapun ketentuan penerimaan atau penolakan apabila angka signifikasi di bawah atau sama dengan 5\% maka $\mathrm{H}_{\mathrm{a}}$ diterima yang berarti signifikan, begitu juga sebaliknya. Berdasarkan Tabel 1 dan 2 maka dapat dijabarkan sebagai berikut:

1) Konstanta sebesar $-300,3 \%$ mengandung arti apabila variabel customer intimacy (X1), promosi (X2), dan citra merek Islam (X3) konstan atau nol, maka loyalitas berada pada angka $-300,3 \%$.

2) Customer intimacy (X1) sebesar $23,8 \%$ bernilai positif dan mempunyai nilai signifikansi sebesar 0,9\% lebih kecil dari koefisien alpha 5\%, menyatakan bahwa customer intimacy berpengaruh positif dan signifikan terhadap loyalitas.

3) Promosi (X2) sebesar 1,9\% bernilai positif serta mempunyai nilai signifikansi sebesar $67,4 \%$ lebih besar dari koefisien alpha 5\%, menyatakan bahwa promosi berpengaruh positif dan tidak signifikan terhadap loyalitas.

4) Citra Merek Islam (X3) sebesar 35,3\% bernilai positif serta mempunyai nilai signifikansi sebesar 0,4\% lebih kecil dari koefisien alpha 5\%, menyatakan bahwa citra merek Islam berpengaruh positif dan signifikan terhadap loyalitas.

5) Kepuasan (Z) sebesar $47,7 \%$ bernilai positif serta mempunyai nilai signifikansi sebesar 0,000 lebih kecil dari koefisien alpha 5\%, menyatakan bahwa kepuasan berpengaruh positif dan signifikan terhadap loyalitas. 
6) Konstanta sebesar $11,3 \%$ menyatakan jika variabel independent dianggap konstan maka rata-rata Kepuasan (Z) akan naik sebesar 11,3 satuan.

7) Customer intimacy (X1) sebesar $4,7 \%$ bernilai positif dan nilai signifikansi sebesar 64,0\% lebih besar dari koefisien alpha 5\%, menyatakan bahwa customer intimacy berpengaruh positif dan tidak signifikan terhadap loyalitas.

8) Promosi (X2) sebesar 1,4\% bernilai positif serta mempunyai nilai signifikansi sebesar 0,787 lebih besar dari koefisien alpha 5\%, menyatakan bahwa promosi berpengaruh positif dan tidak signifikan terhadap loyalitas.

9) Citra merek Islam (X3) sebesar $91,0 \%$ bernilai positif serta mempunyai nilai signifikansi sebesar 0,000 lebih kecil dari koefisien alpha 5\%, menyatakan bahwa citra merek Islam berpengaruh positif dan signifikan terhadap Loyalitas.

\section{Path Analysis}

Tujuan dari Uji Path adalah untuk memperkirakan hubungan sebab akibat antara variabel yang telah ditetapkan berdasarkan teori. Hubungan kausal antar variabel telah dibentuk dengan model berbasis teori dasar menggunakan pola hubungan antara tiga variabel atau lebih dan tidak dapat digunakan untuk mengkonfirmasi atau menolak hipotesis kualitas imajiner (Ghozali, 2013). Model kerangka jalur dalam penelitian ini dapat dilihat pada Gambar 1. sebagai berikut:

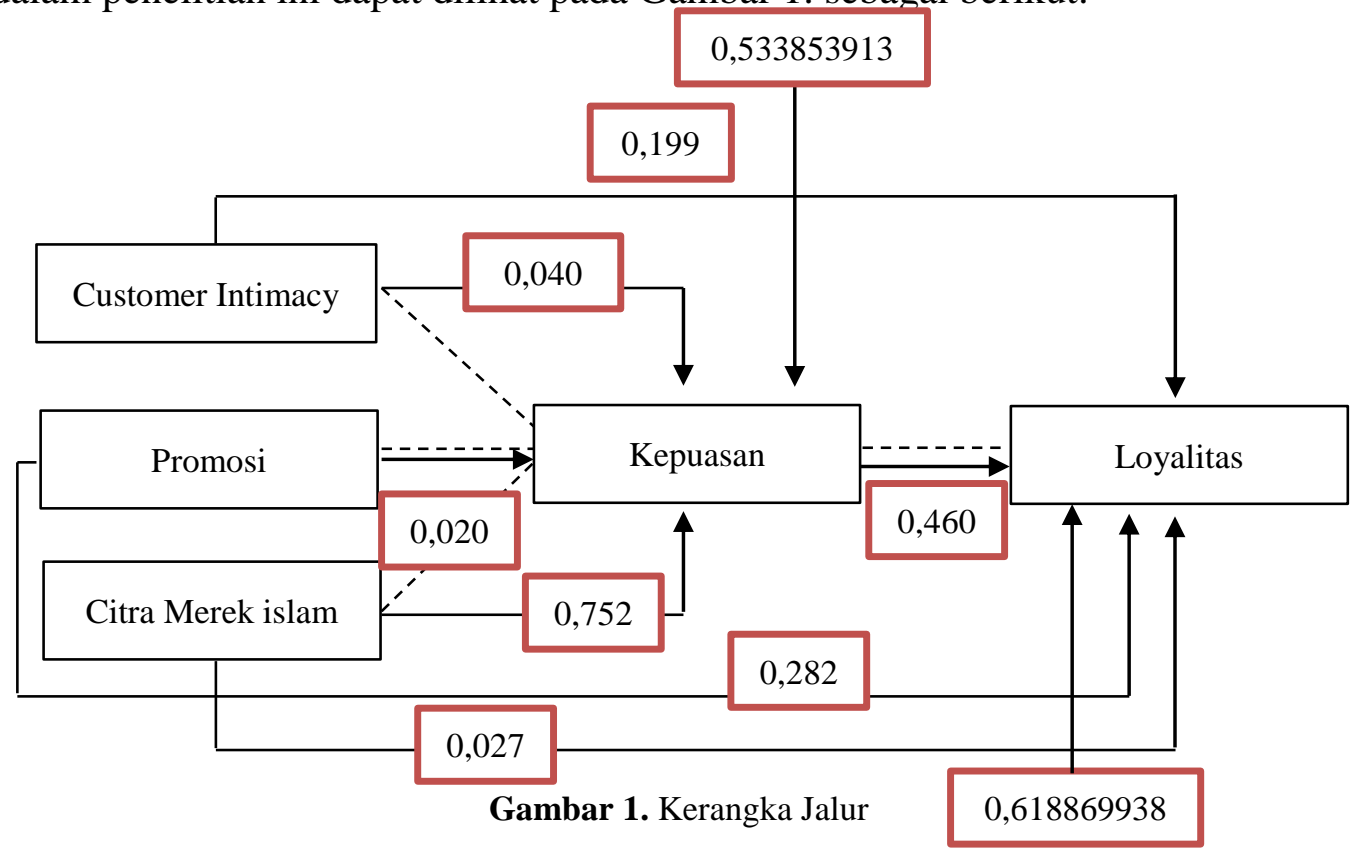


Berdasarkan Gambar 1, maka menunjukkan mengenai nilai koefisien jalur untuk variabel customer intimacy sebesar 39,495\%, variabel promosi sebesar 39,103\%, dan variabel citra merek Islam sebesar 419,041\%.

\section{PEMBAHASAN}

\section{Customer Intimacy, Promosi, dan Citra Merek Islam terhadap Loyalitas}

Hasil penelitian menunjukkan bahwa customer intimacy berpengaruh positif signifikan terhadap loyalitas. Dilihat dari uji t test yang dapat dilihat pada tabel 1.1, terlihat jika customer intimacy (X1) memiliki jumlah koefisiensi 23,8\% yang dengan signifikansi $0,9 \%$ di bawah 5\%. Artinya customer intimacy yang dilakukan BSI KCP Godean 3 mempengaruhi tingkat loyalitas nasabah. Hasil penelitian ini sejalan dengan penelitian yang dilakukan oleh (Anggriawan et al., 2015) yang menunjukkan bahwa customer intimacy berpengaruh terhadap loyalitas nasabah.

Promosi berpengaruh positif tidak signifikan terhadap loyalitas nasabah merujuk pada teble 1.1, dapat diketahui jika variabel Promosi (X2) memiliki koefisiensi sebesar 1,9\% dengan tingkat signifikansi 67,4\% lebih dari 5\%. Artinya promosi yang dilakukan oleh BSI KCP Godean 3 tidak mempengaruhi tingkat keloyalan nasabah. Hasil penelitian ini didukung oleh (Agustina \& As'ad, 2018) yang menyatakan bahwa dikarenakan promosi yang digunakan oleh perusahaan belum sepenuhnya tepat dan maksimal kepada nasabah.

Citra merek Islam berpengaruh positif dan signifikan terhadap loyalitas nasabah. merujuk pada tabel 1.1, dapat diketahui jika citra merek Islam (X3) memiliki koefisiensi beerjumlah 35,3\% dengan signifikansi 0,4\% kurang dari 5\%. Hal ini menunjukkan bahwa nilai islam yang ada di merek tersebut merupakan faktor yang mempengaruhi keloyalitasan nasabah BSI KCP Godean 3. Hasil penelitian ini sejalan dengan penelitian yang dilakukan oleh (Hisanuddin, 2015) yang menunjukkan bahwa citra merek Islam berpengaruh secara positif dan signifikan.

\section{Kepuasan terhadap Loyalitas}

Hasil penelitian ini menunjukkan bahwa kepuasan berpengaruh positif dan signifikan terhadap loyalitas nasabah. merujuk pada teble 1.1, dapat diketahui jika 
variabel kepuasan (Z) memiliki koefisiensi sejumlah 47,7\% dengan signifikansi 0,000 kurang dari 5\% Hal ini menunjukkan bahwa kepuasan yang diberikan oleh perusahaan sangat berpengaruh terhadap loyalitas nasabah. Kepuasan bisa terjadi karena beberapa faktor kebutuhan dan keinginan nasabah terpenuhi. Hasil penelitian ini sejalan dengan penelitian yang dilakukan oleh (Ramadhani, 2020) dalam penelitiannya menjelaskan bahwa kepuasan berpengaruh positif dan signifikan terhadap loyalitas.

\section{Customer Intimacy, Promosi, dan Citra Merek Islam terhadap Kepuasan}

Hasil penelitian menunjukkan bahwa customer intimacy berpengaruh positif dan tidak signifikan terhadap kepuasan merujuk pada tebel 1.1, dapat diketahui jika customer intimacy (X1) memiliki koefisiensi 4,7\% dengan signifikansi 64,0\% lebih dari 5\%. Artinya customer intimacy yang dilakukan oleh perusahaan tidak akan mempengaruhi keuasan nasabah BSI KCP Godean 3 karena nasabah kurang merasa mendapatkan perhatian khusus dari perusahaan. Hasil penelitian ini sejalan dengan penelitian yang dilakukan oleh (Suprijati, 2018) dalam penelitiannya menjelaskan bahwa customer intimacy berpengaruh positif dan signifikan terhadap kepuasan.

Promosi berpengaruh positif dan tidak signifikan terhadap kepuasan merujuk pada tebel 1.1, dapat diketahui jika promosi (X2) memiliki koefisiensi 1,4\% dengan signifikansi 78,7\% lebih dari 5\%. Artinya promosi yang dilakukan BSI KCP Godean 3 belum sepenuhnya bisa menarik nasabah dan belum ada rasa kepuasan tersendiri yang diterima oleh nasabah. Hal ini sejalan dengan penelitian yang dilakukan oleh (Agustina \& As'ad, 2018) yang menyatakan bahwa promosi tidak memberikan pengaruh signifikan terhadap kepuasan nasabah.

Citra merek Islam berpengaruh positif dan signifikan terhadap kepuasan merujuk pada tebel 1.1, dapat diketahui jika variabel citra merek Islam (X3) memiliki koefisiensi 91,0\% dengan signifikansi 0,000 lebih kecil dari 5\%. Hal ini menunjukkan bahwa citra merek Islam mampu membuat nasabah menjadi yakin bahwa produk yang digunakan itu halal dan sesuai dengan syariat Isam oleh karena itu nasabah akan menjadi puas. Hasil dari penelitian ini sejalan dengan 
penelitian yang dilakukan oleh (Wibowo, 2017) menjelaskan bahwa citra merek Islam berpengaruh positif dan signifikan terhadap kepuasan.

\section{Kemampuan kepuasan memediasi customer intimacy, promosi, dan citra merek Islam}

Kepuasan tidak mampu memediasi pengaruh customer intimacy terhadap loyalitas. Merujuk pada gambar 1 dijelaskan bahwa variabel customer intimacy intimacy (X1) menghasilkan $t_{\text {hitung }}$ sebesar 39,495\% $<1,661$ dengan nilai signifikansi 5\%. Artinya semakin tinggi customer intimacy dari nasabah tidak akan mempengaruhi tinggi/ rendahnya nasabah dalam keloyalan. Hal ini sejalan dengan penelitian yang dilakukan oleh (Rozi et al., 2016) dalam penelitiannya menjelaskan bahwa kepuasan tidak dapat memediasi customer intimacy terhadap loyalitas nasabah.

Kepuasan tidak mampu memediasi pengaruh promosi terhadap loyalitas. Merujuk pada gambar 1 dijelaskan bahwa variabel promosi (X2) menghasilkan $t_{\text {hitung }}$ sebesar 39,103\% < 1,661 dengan nilai signifikansi 5\%. Artinya Semakin tinggi promosi yang dilakukan perusahaan tidak akan mempengaruhi tinggi rendahnya dia untuk menjadi loyal, biasanya nasabah tertarik dengan perusahaan tersebut karena keinginan dirinya sendiri. Hasil penelitian ini sejalan dengan penelitian yang dilakukan oleh (Hidayah, 2019) yang menjelaskan bahwa kepuasan tidak dapat memediasi promosi terhadap loyalitas nasabah.

Kepuasan mampu memediasi pengaruh citra merek Islam terhadap loyalitas. Merujuk pada gambar 1 dijelaskan bahwa variabel citra merek Islam (X3) menghasilkan $t_{\text {hitung }}$ sebesar 419,041\% lebih besar > 1,661 nilai signifikansi $5 \%$. Artinya semakin tinggi citra Islam yang diberikan perusahaan akan semakin meyakinkan nasabah dalam menggunakan produk maupun jasa yang di sediakan oleh BSI KCP Godean 3. Nasabah banyak yang menjadikan agama sebagai patokan dalam melakukan konsumsi maka hal ini akan mempengaruhi nasabah menjadi loyal. Penelitian ini sejalan dengan penelitian yang dilakukan oleh (Hidayah, 2019) yang menjelaskan bahwa kepuasan tidak dapat memediasi promosi terhadap loyalitas nasabah. 


\section{KESIMPULAN}

Berdasarkan hasil analisis data serta pembahasan dalam penelitian ini maka bisa ditarik kesimpulan bahwa:

1. Customer intimacy dan citra merek Islam berpengaruh positif signifikan terhadap loyalitas. Pernyataan tersebut menunjukkan jika customer intimacy dan citra merek Islam mengalami peningkatan ataupun penurunan maka akan berpengaruh terhadap loyalitas nasabah. Sedangkan promosi berpengaruh positif dan tidak signifikan terhadap loyalitas. Ini menunjukkan jika promosi mengalami peningkatan ataupun penurunan maka tidak akan berpengaruh terhadap loyalitas nasabah.

2. Kepuasan berpengaruh positif dan signifikan terhadap loyalitas. Pernyataan tersebut menunjukkan jika kepuasan mengalami peningkatan ataupun penurunan maka akan berpengaruh terhadap loyalitas nasabah.

3. Customer intimacy dan promosi berpengaruh positif dan tidak signifikan terhadap kepuasan. Pernyataan tersebut menunjukkan jika customer intimacy dan promosi mengalami peningkatan ataupun penurunan maka tidak akan berpengaruh terhadap kepuasan. Sedangkan citra merek Islam berpengaruh positif signifikan terhadap kepuasan nasabah maka jika citra merek Islam mengalami peningkatan atau penurunan akan berpengaruh terhadap kepuasan.

4. Kepuasan tidak mampu memediasi pengaruh customer intimacy dan promosi terhadap loyalitas, artinya pengaruh customer intimacy dan promosi terhadap loyalitas adalah secara langsung atau tidak melalui kepuasan terlebih dahulu. Sementara kepuasan mampu memediasi citra merek Islam terhadap loyalitas, artinya pengaruh citra merek Islam terhadap loyalitas adalah secara tidak langsung namun melalui variabel kepuasan terlebih dahulu.

\section{UCAPAN TERIMAKASIH}

Terimakasih kepada semua pihak yang telah membantu penyelesaian penelitian ini dalam bentuk doa maupun dukungan semangat yang diberikan. Sehingga tanpa adanya semua itu penulisan penelitian tidak akan bisa tercapai dengan maksimal. 


\section{DAFTAR PUSTAKA}

Agustina, T. M., \& As'ad, S. (2018). Pengaruh Kualitas Pelayanan dan Promosi

Terhadap Loyalitas dan Kepuasan Nasabah di BMT Bina Ihsanul Fikri Yogyakarta. Ekulibrium, 13(2).

Anggriawan, F., Widodo, D., \& Kartini, T. (2015). Pengaruh Customer Intimacy

Terhadap Loyalitas Nasabah Bank Rakyat Indonesia Syariah Cabang Jember.

Artikel Ilmiah Mahasiswa, 1(1), 1-7.

Ghozali, I. (2011). Aplikasi Analisis Multivariate dengan Program SPSS.

Universitas Diponegoro.

Ghozali, I. (2013). Aplikasi Analisis Multivariate dengan Program SPSS (Edisi

Ketu). Badan Penerbit Universitas Diponegoro.

Hafil, M. (2021). BSI Boyong Lima Penghargaan dari InfoBank|Republika

Online.Www.Republika.Co.Id.https://www.republika.co.id/berita/qvgth9430/

bsi-boyong-lima-penghargaan-dari-infobank

Hidayah, S. N. (2019). Pengaruh Promosi, Kualitas produk, Kepercayaan, dan Kualita Pelayanan Terhadap Loyalitas Nasabah dengan Kepuasan Nasabah

Sebagai Variabel Intervening (Studi pada Nasabah BRI Syariah KCP Majapahit) Skripsi.

Hisanuddin, L. I. (2015). Pengaruh Citra Merek Islam terhadap Loyalitas Nasabah

Bank syariah. Scientica, II(2).

Koyong, M. D., Sumayku, S., \& Kalangi, J. (2016). Pengaruh promosi terhadap loyalitas nasabah di PT. Bank Mandiri Kantor Cabang Dotulolong Lasut Manado. Administrasi Bisnis, 4, 7.

Ramadhani, A. A. (2020). Analisis Pengaruh Kepercayaan dan Kepuasan Terhadap Loyalitas Pelanggan Jasa Delivery Cak Ed Lamongan. JEKMA, 1(1).https://jurnalekonomi.unisla.ac.id/index.php/JEKMA/article/view/411/3 24

Ranto, D. W. P. (2013). Menciptakan Islamic Branding Sebagai Strategi Menarik Minat Beli Konsumen. Jurnal Bisnis, Manajemen, Dan Akuntansi, 1(2), 111. 
Razak, A., \& Oliver. (2018). Pengaruh Kepuasan dan Kepercayaan Terhadap Loyalitas Nasabah pada Bank Negara Indonesia Cabang Kendari. Journal Economic and Business, 1(2), 10-20.

Rozi, A. F., Sularso, R. A., \& Dimyati, M. (2016). Dampak Elemen Customer Relationship Marketing Terhadap Loyalitas Pelanggan Rumah Makan Bebek 88. Ilmiah Inovasi, 14(2).

Sarwita, H. A. (2017). Pengaruh Kualitas Pelayanan dan Promosi Terhadap Keputusan Nasabah untuk Menabung. Ilmiah Manajemen \& Akuntansi, 4(1).

Sidabutar, C. B., \& Dharmayanti, D. (2015). Analisa Pengaruh Brand Experience Terhadap Customer Loyality Melalui Brand Trust, Customer Satisfaction dan Customer Intimacy Sebagai Variabel Intervening. Manajemen Pemasaran Petra, 1(1), 1-10.

Suprijati, J. (2018). Analisis Pengaruh Value Chain Customer Relationship Management Terhadap Kepuasan Pelanggan Pada PT. POS Indonesia di Gersik. https://doi.org/10.21107/KOMPETENSI.V10I2.3522

Warindrasti, R., \& Pratama, A. A. N. (2021). Mampukah kepusan konsumen memediasi pengaruh personal selling, direct selling, dan nilai-nilai islam. Journal of Management and Digital Business, 1(1), 27.

Wibowo, B. S. (2017). Pengaruh Kualitas Layanan dan Citra Merek Terhadap Kepuasan Nasabah Centratama Nasional Bank Surabaya. JPIM (Jurnal Penelitian Ilmu Manajemen), 2(1), 27 Halaman. https://doi.org/10.30736/ JPIM.V2I1.41

www.bankbsi.co.id. (2021). Bank Syariah Indonesia. Www.Ir-Bankbsi.Com/ Corporate_history.Html.https://www.irbankbsi.com/corporate_history.html 